\title{
Menjamin Hak Perempuan dengan Taklik Talak dan Perjanjian Perkawinan
}

\author{
Khoiruddin Nasution \\ Universitas Islam Negeri Sunan Kalijaga \\ khoiruddin@yahoo.com
}

The concepts of taklik talak and/or marital agreement have been recognized in Indonesia for long time. However, those who are knowledgeable of them are still limited to certain people. Since the first time until their appearance in the Marriage Law and regulations, the taklik talak and/or marital agreement have been intended to guarantee the rights of wives and to protect them from discriminative and arbitrary actions of husbands. Despite their long existence, the concepts have not been fully conceived by society in general. This lack of understanding of the concepts has been caused by lack of socialization, and therefore, the socialization should be continuously and substantially done.

Keywords: marital agreement, wives, discriminative and arbitrary, socialization.

\section{Pendahuluan}

$\mathrm{P}$ embaruan Hukum Keluarga Islam (Hukum Perkawinan dan Perceraian) dimulai tahun 1917 oleh Turki. Usaha Turki ini diikuti Mesir tahun 1920. Usaha yang sama dilakukan sejumlah Negara muslim lainnya. Walhasil, sampai tahun 1996, di negara Timur Tengah misalnya, hanya tinggal lima negara yang belum memperbaharuai hukum keluarga, bahkan negaranegara ini pun sedang dalam proses pembuatan draft, yakni Emirat Arab, Saudi Arabia, Qatar, Bahrain dan Oman (Alami dan Hinchliffe, 1996 dan Mudzhar \& Nasution, 2003).

Adapun yang memberikan inspirasi pentingnya pembaruan Hukum Keluarga Islam menurut catatan Anderson awalnya berasal dari luar, baik dari missionaries Kristen maupun dampak umum penjajahan barat. Namun inspirasi ini memberikan kesadaran baru bagi sejumlah ilmuwan
Muslim. Untuk menyebut di antaranya adalah Muhammad Abduh, Qasim Amin dari Mesir, dan Ameer Ali dari India (Anderson,1968).

Tujuan usaha pembaruan ini secara umum dapat dikelompokkan menjadi tiga. Pertama, unifikasi hukum perkawinan. Kedua, peningkatan status wanita. Ketiga, respon terhadap dan menyesuaikan dengan perkembangan dan tuntutan zaman. Ada juga yang menambahkan untuk tujuan kepastian hukum. Dalam upaya peningkatan status perempuan dapat dikategorikan secara umum menjadi dua. Pertama, menjamin hak-hak mereka. Kedua, melindungi mereka dari perlakukan sewenang-wenang suami. Jabaran dari upaya jaminan dan perlindungan ini muncul dalam berbagai bentuk aturan. Di antara aturan yang ada dalam Perundang-undangan Perkawinan Indonesia adalah diberikan kesempatan kepada perempuan untuk membuat taklik talak dan atau perjanjian 
UNISIA, Vol. XXXI No. 70 Desember 2008

perkawinan. Tulisan ini menyajikan bagaimana kesempatan yang diberikan kepada perempuan untuk menjamin hak mereka sekaligus melindungi mereka dari perbuatan semena-mena suami lewat taklik talak dan atau perjanjian perkawinan. Fokus kajian tulisan ini adalah Perundang-Undangan Perkawinan Indonesia.

\section{Kajian Pustaka}

\section{Sejarah Taklik Talak Indonesia}

Sebelum dijelaskan bagaimana konsep taklik talak dan perjanjian perkawinan dalam Perundang-Undangan Perkawinan Indonesia, lebih dahulu dijelaskan secara singkat apa yang dimaksud dengan taklik talak dan/ atau perjanjian perkawinan. Dengan demikian ada dua kata yang pemakaiannya dalam Perundang-Undangan Perkawinan Indonesia hampir sama. Demikian juga kedua istilah yang digunakan ini mempunyai tujuan yang sama, yakni untuk menjamin hak dan melindungi perempuan (isteri) dari tindakan diskriminatif dan sewenang-wenang laki-laki (suami). Bahkan dalam rancangan amandemen draf kesepuluh UndangUndang R.I. tentang Hukum Terapan Peradilan Agama bidang Perkawinan lebih tegas disebutkan taklik talak dan atau perjanjian perkawinan. Sebab dalam KHI hanya ada kata 'perjanjian perkawinan', (bab VII, pasal 45/52), sementara dalam draf baru dicantumkan 'taklik talak dan perjanjian perkawinan' (Bab VII, pasal 38 \& 39 - 44).

Kata taklik talak terdiri dari dua kata, yakni taklik dan talak. Kata taklik dari kata arab 'allaqa yu'alliqu ta'lîqan (Yunus,tt), yang berarti menggantungkan. Sementara kata talak dari kata arab tallaqa yutalliqu tatlíqan, yang berarti mentalak, menceraikan atau kata jadi 'perpisahan'. Maka dari sisi bahasa, taklik talak berarti talak yang digantungkan.
Artinya, terjadinya talak (perceraian) atau perpisahan antara suami dan isteri yang digantungkan terhadap sesuatu.

Sementara kalau dilihat penggunaannya, seperti dalam praktik di Indonesia, taklik talak adalah terjadinya talak (perceraian) atau perpisahan antara suami dan isteri yang digantungkan kepada sesuatu, dan sesuatu ini dibuat dan disepakati pada waktu melakukan akad nikah. Maka pelanggaran terhadap apa yang disepakati inilah yang menjadi dasar terjadinya perceraian (talak) atau perpisahan. Berdasarkan substansi inilah menjadi dasar untuk mengatakan bahwa taklik talak pada prinsipnya sama dengan perjanjian perkawinan yang dapat menjadi dasar dan alasan terjadinya perceraian atau perpisahann antara suami dan isteri. Misalnya dalam buku nikah Indonesia, sighat ta'lik, berisi perjanjian perkawinan. Bahkan di awal shigat ini juga diawali dengan ayat al-Qur'an yang memerintahkan untuk menepati janji, yakni surah Bani Israil/al-Isra' (17): 34: yang Artinya: .... dan penuhilah janji, sesungguhnya janji itu pasti diminta pertanggungjawaban.

\section{Perdebatan Sighat}

Namun demikian, ada penegasan dalam penjelasan $\mathrm{Bab}$ V, pasal 29 UndangUndang No. 1 Tahun 1974 tentang Perkawinan, bahwa perjanjian perkawinan tidak masuk taklik talak. Sebaliknya, dalam Bab VII, pasal 45 Kompilasi Hukum Islam Indonesia (KHI) disebutkan bahwa perjanjian perkawinan dapat dalam bentuk taklik talak dan perjanjian lain yang tidak bertentangan dengan hukum Islam. Dengan demikian, dari sisi materi, isi UU No. 1 tahun 1974 tentang Perkawinan, tentang taklik talak dan perjanjian perkawinan telah dihapus dan dilengkapi oleh $\mathrm{KHI}$ yang pemberlakuannya adalah lebih belakangan, yakni tahun 1990. 
Menjamin Hak Perempuan...; Khoiruddin Nasution

Lebih jauh dalam buku nikah disebutkan sighat ta'lik yang diucapkan sesudah akad nikah sebagai berikut:

Bismillah al-rahman al-rahim

Sesudah akad nikah, saya ....... bin .... berjanji dengan sesungguh hati, bahwa saya akan menepati kewajiban saya sebagai seorang suami, dan akan saya pergauli istri saya bernama ... binti .... dengan baik (mu'âsyarah bil-ma'rûf) menurut ajaran syari'at Islam.

Selanjutnya saya mengucapkan sighat ta'lik atas istri saya itu sebagai berikut:

Sewaktu-waktu saya:

1) meninggalkan isri saya tersebut dua tahun berturut-turut.

2) Atau saya tidak memberi nafkah wajib kepadanya tiga bulan lamanya,

3) Atau saya menyakiti badan/jasmani istri saya itu,

4) Atau saya membiarkan (tidak memperdulikan) istri saya itu enam bulan lamanya, kemudian istri saya tidak ridla dan mengadukan halnya kepada Pengadilan Agama atau petugas yang diberi hak mengurus pengaduan itu, dan pengaduan dibenarkan serta diterima oleh pengadilan atau petugas tersebut, dan istri saya itu membayar uang sebesar Rp.1000,- (seribu rupiah) sebagai i'wadl (pengganti) kepada saya, maka jatuhlah talak saya satu kepadanya.

Kepada pengadilan atau petugas tersebut tadi saya kuasakan untuk menerima uang 'wald (pengganti) itu dan kemudian menyerahkannya kepada Badan Kesejahteraan Masjid (BKM) Pusat untuk keperluan ibadah sosial.

Sighat ta'lik yang dicatat tersebut di atas adalah sighat taklik Indonesia. Isi dalam sighat tersebut adalah perjanjian perkawinan antara suami dan isteri. Dengan demikian menjadi semakin jelas bahwa taklik talak pada prinsipnya sama dengan perjanjian perkawinan. Artinya, taklik talak merupakan bagian dari perjanjian perkawinan. Dengan ungkapan lain, perjanjian perkawinan dapat dalam bentuk taklik talak dan dapat pula dalam bentuk lain di luar taklik talak.

Sejalan dengan isi sighat taklik tersebut, maka taklik talak dalam Perundang-undangan Perkawinan Indonesia pun masuk pada pasal perjanjian perkawinan, yang tercantum pada bab v, pasal 29 Undang-Undang No. 1 tahun 1974 tentang Perkawinan. Demikian juga perjanjian perkawinan dicantumkan dalam Kompilasi Hukum Islam Indonesia (KHI), yang diatur dalam bab vii: Perjanjian Perkawinan (pasal 45 s/d 52).

Untuk mengetahui sejarah perkembangan taklik talak sedikit lebih rinci di Indonesia dapat dijelaskan berikut. Menurut catatan yang ada, pelembagaan taklik talak dimulai dari perintah Sultan Agung Hanyakrakusuma, raja Mataram (1554 Jawa / 1630 Masehi) dalam upaya memberi kemudahan bagi wanita untuk melepaskan ikatan perkawinan dari suami yang meninggalkan isteri (keluarga) pergi dalam jangka waktu tertentu untuk melaksanakan tugas. Disamping itu taklik talak ini menjadi jaminan bagi suami bila kepergian itu adalah dalam rangka tugas Negara. Taklik itu disebut Taklek Janji Dalem atau taklek janjiningratu. Artinya taklik talak dalam kaitan dengan tugas negara, yang aslinya berbunyi:

Mas Penganten, pekenira tompo Taklek Jangji Dalem, samongso pekanira nambang (ninggal) rabi pakenira .......' lawase pitung sasi lakon daratan, hutawa nyabrang sagara rong tahun, saliyane ngelakoni hayahan dalem, tan terimane rabi pakenira nganti darbe hatur rapak 
UNISIA, Vol. XXXI No. 70 Desember 2008

(sowan) hing pangadilan hukum, sawuse terang papriksane runtuh talak pakanira sawijiâ'.

Bahasa Indonesianya :

'Wahai penganten, dikau memperoleh Taklik Janji Dalem, sewaktu-waktu dikau menambang (meninggalkan) isterimu bernama ....... selama tujuh bulan perjalanan darat, atau menyeberang lautan dua tahun, kecuali dalam menjalankan tugas Negara, dan isterimu tidak rela sehingga mengajukan rapak (menghadap) ke pengadilan hukum, setelah jelas dalam pemeriksaannya, maka jatuhlah talakmu satu'.

Taklik ini tidak dibaca oleh penganten pria, tetapi diucapkan oleh Penghulu Naib dan cukup dengan dijawab: Hinggih sendika (iya saya bersedia) (Noeh, 1997).

Menurut Zaini Ahmad Noeh, pelembagaan taklik talak dan gono-gini yang terjadi pada masa kerajaan Mataram merupakan pengembangan dari pemikiran dan pemahaman ulama terhadap hukum Islam, terutama yang berkaitan dengan masalah talak (perceraian) atau perpisahan antara suami dan isteri (Arifin,1994)).

Setelah Belanda datang ke Indonesia didapati kenyataan bahwa taklik talak telah hidup dalam masyarakat. Yang pertama kali menemukan taklik talak yang dalam bahasa Belanda disebut voorwaardelijke verstoting di Indonesia adalah Snouck Hurgronje ketika membahas masalah hukum adat.

Seiring perkembangan masyarakat Indonesia, rumusan taklik talak juga mengalami perubahan, baik dari aspek unsur-unsur maupun dari redaksionalnya. Ketika sighat taklik talak diberlakukan pertamakali di Kerajaan Mataram unsurunsurnya ada 4 (empat) yakni :

1. Pergi meninggalkan,
2. Isteri tidak rela,

3. Isteri mengadu ke Pengadilan,

4. Pengaduannya diterima Pengadilan.

Hal ini terlihat dari rumusan sighat taklik talak sebagaimana dikutip di atas.

Dari 4 (empat) unsur di atas, dapat disimpulkan bahwa hanya unsur pergi meninggalkan yang dijadikan dasar isteri untuk mengadu ke pengadilan sebagai alasan perceraian (taklik talak). Lamanya waktu meninggalkan tersebut adalah 7 (tujuh) bulan untuk kepergian suami menggunakan perjalanan darat, 2 (dua) tahun untuk kepergian suami menyeberangi lautan.

Pada tahun 1931 ketika taklik talak diberlakukan di sekitar Jakarta dan Tangerang, rumusan sighat taklik talak mengalami penambahan, terutama dari aspek unsur-unsurnya. Demikian juga mengalami perubahan dari aspek jangka waktunya. Rumusan lengkapnya adalah sebagai berikut:

1) Tiap-tiap saya tinggalkan isteri saya dengan semata-mata tinggal jalan darat tiga bulan atawa jalan laut dalam masa enam bulan lamanya;

2) Atawa saya tidak kasih nafkah yang wajib pada saya dalam masa satu bulan lamanya;

3) Atawa saya pukul akan dia dengan pukulan yang menyakiti padanya;

4) Maka jika isteri saya itu tidak suka akan salah satu yang tersebut di atas itu, ia boleh pergi sendiri atau wakilnya mengadukan halnya kepada Raad Agama, serta ia minta bercerai dan manakala isteri saya yang tersebut itu membayar pada saya uang banyaknya f 0,10 (sepuluh Cent) serta sabit dakwaannya, tertalaklah isteri saya yang tersebut satu talak dan dari uang iwadl khulâ yang tersebut saya 
Menjamin Hak Perempuan...; Khoiruddin Nasution

wakilkan kepada Raad Agama buat kasih sedekah kepada fakir miskin.

Dari rumusan tersebut tampak jelas terjadi penambahan unsur-unsurnya, sebanyak dua unsur, yakni :

1. tidak memberi nafkah,

2. memukul isteri yang bersifat menyakiti,

Dari unsur intensitas waktunya juga mengalami perubahan dari 7 (tujuh) bulan menjadi 3 (tiga) bulan jalan darat, dari 2 (dua) tahun menjadi 6 (enam) bulan jalan laut.

Setelah Indonesia merdeka, rumusan sighat taklik talak ditentukan sendiri oleh Departemen Agama Republik Indonesia. Hal ini dimaksudkan agar penggunaan rumusan sighat taklik talak tidak disalahgunakan secara bebas yang mengakibatkan kerugian bagi pihak suami atau isteri, atau bahkan bertentangan dengan tujuan hukum syara:

Sejak berlakunya Undang-undang Nomor 22 Tahun 1946 jo. Undang-undang Nomor 32 Tahun 1952, maka ketentuan tentang sighat taklik talak diberlakukan seragam di seluruh Indonesia. Sejak rumusannya diambil alih Depag, sighat taklik talak mengalami beberapa kali perubahan. Perubahan tersebut tidak hanya mengenai unsur-unsur pokoknya, tetapi juga mengenai kualitas syarat taklik yang bersangkutan dan besarnya uang iwadl.

Perubahan tersebut menurut Abdul Manan tidak lepas dari misi awal pelembagaan sighat taklik talak, yakni dalam rangka melindungi isteri dari kesewenang-wenangan suami. Disamping itu, perubahan dimaksudkan agar lebih mendekati kepada kebenaran hukum Islam.

Adapun unsur-unsur yang mengalami perubahan adalah seperti rumusan ayat (3) sighat taklik talak. Pada tahun 1950 disebutkan: 'atau saya menyakiti isteri saya itu dengan memukul', dimana pengertian memukul disini hanya terbatas pada memukul saja. Pada tahun 1956 pengertian memukul diperluas sampai kepada segala perbuatan suami yang dapat dikatagorikan menyakiti badan jasmani, seperti menendang, mendorong sampai jatuh, menjambak rambut, membenturkan kepala ke tembok dan sebagainya. Dari sudut rentang waktu juga mengalami perubahan, seperti rumusan ayat (1) sighat taklik talak tentang lamanya pergi meninggalkan isteri, pada tahun 1950, 1956 dan 1969 ditetapkan menjadi 2 (dua) tahun. Sedang ayat (4) sighat taklik talak tentang lamanya membiarkan/ tidak memperdulikan isteri, pada tahun 1950 ditetapkan selama 3 (tiga) bulan, pada rumusan tahun 1956 menjadi 6 (enam) bulan. Perubahan jangka waktu ini dimaksudkan untuk mempersulit terpenuhi syarat sighat taklik talak, sekaligus memperkecil terjadinya perceraian.

Rumusan terakhir sighat taklik talak adalah rumusan yang ditetapkan berdasarkan Peraturan Menteri Agama RI Nomor 2 Tahun 1990, yang rumusan lengkapnya adalah sebagai berikut:

Sesudah akad nikah, saya ...... bin ....... berjanji dengan sesungguh hati, bahwa saya akan menepati kewajiban saya sebagai seorang suami, dan akan saya pergauli isteri saya bernama ..... binti ....... dengan baik (mu'âsyarah bil ma'rûf) menurut ajaran syari'at Islam. Selanjutnya saya mengucapkan sighat taklik atas isteri saya itu sebagai berikut:

Sewaktu-waktu saya (1) Meninggalkan isteri saya dua tahun berturut-turut, (2) Atau saya tidak memberi nafkah wajib kepadanya tiga bulan lamanya, (3) Atau saya menyakiti badan/jasmani isteri saya, (4) Atau saya membiarkan (tidak memperdulikan) isteri saya enam bulan lamanya. 
UNISIA, Vol. XXXI No. 70 Desember 2008

Kemudian isteri saya tidak ridha dan mengadukan halnya kepada Pengadilan Agama atau petugas yang memberinya hak untuk mengurus pengaduan itu dan pengaduannya dibenarkan serta diterima oleh Pengadilan atau petugas tersebut, dan isteri saya membayar uang sebesar $R p$. 1.000,- (seribu rupiah) sebagai iwadh (penggati) kepada saya, maka jatuhlah talak saya satu kepadanya. Kepada Pengadilan atau petugas tersebut tadi saya kuasakan untuk menerima uang iwadh (pengganti) itu dan kemudian menyerahkannya kepada Badan Kesejahteraan Masjid (BKM) Pusat, untuk perluan ibadah social.

Dari rumusan tersebut ada 10 unsurunsur pokok sighat taklik talak yakni:

1. Suami meninggalkan isteri, atau;

2. Suami tidak memberi nafkah kepada isteri, atau;

3. Suami menyakiti isteri, atau;

4. Suami membiarkan tidak (memperdulikan) isteri;

5. Isteri tidak rela;

6. Isteri mengadu ke Pengadilan;

7. Pengaduan isteri diterima oleh Pengadilan;

8. Isteri membayar uang iwadh;

9. Jatuhnya talak satu suami kepada isteri;

10. Uang iwadh oleh suami diterimakan kepada Pengadilan untuk selanjutnya diserahkan kepada pihak ketiga untuk kepentingan ibadah sosial.

Dari unsur-unsur di atas terlihat bahwa alasan taklik talak pada dasarnya hanya ada empat, yakni:

1. Suami meninggalkan isteri, atau;

2. Suami tidak memberi nafkah kepada isteri, atau;

3. Suami menyakiti isteri, atau;

4. Suami membiarkan tidak (memperdulikan) isteri;

Namun kemudian masalah mengu- capkan sighat taklik talak selepas akad nikah dipersoalkan oleh masyarakat Indonesia dengan beberapa alasan. Akhirnya dengan Keputusan MUI pada tanggal 23 Rabiul Akhir 1417 H., bertepatan dengan 7 September 1996, mengucapkan shigat taklik talak tidak diperlukan lagi. Adapun alasan keputusan ini dapat digambarkan sebagai berikut. Pertama, bahwa meteri shigat taklik talak pada dasarnya telah dipenuhi dan tercantum dalam UndangUndang No. 1 Tahun 1974 tentang Perkawinan dan Undang-Undang No. 7 Tahun 1989 tentang Peradilan Agama. Kedua, menurut Kompilasi Hukum Islam $(\mathrm{KHI})$, perjajian taklik talak bukan merupakan keharusan dalam setiap perkawinan $(\mathrm{KHI}$ pasal 46 ayat 3). Ketiga, bahwa konteks mengucapkan shigat taklik talak menurut sejarahnya adalah untuk melindungi hak-hak wanita, dimana waktu itu taklik talak belum ada dalam peraturan perundang-undangan perkawinan. Karena itu, setelah adanya aturan tentang itu dalam peraturan perundang-undangan perkawinan, maka mengucapkan shigatnya tidak diperlukan lagi. ${ }^{11}$

Namun dicatat juga, bahwa kontekstualisasi munculnya perdebatan perlu atau tidaknya mengucapkan sighat taklik talak selepas akad nikah lebih pada pertimbangan waktu yang dibutuhkan, bukan masalah materi. Sebab di beberapa daerah jumlah pegawai pencatat nikah belum seimbang dengan kebutuhan, ditambah dengan kebiasaan pelaksanaan perkawinan pada bulan-bulan tertentu. Bahkan di beberapa daerah ada keyakinan bahwa pelaksanaan perkawinan diyakini harus dilaksanakan dalam jam dan menit tertentu. Sementara kalau dilaksanakan di luar waktu atau jam dan menit tersebut mengakibatkan atau minimal dikhawatirkan mengakibatkan perkawinan tidak langgeng atau kurang 
berhasil. Dalam kondisi dan dalam upaya menjembatani keyakinan sejenis ini para penghulu berinisiatif awalnya sighat taklik talak dibacakan tetapi tidak harus di depan penghulu. Sebab waktu untuk membacakan sighat taklik talak cukup menyita waktu bagi penghulu. Akhirnya lama kelamaan tradisi membaca sighat taklik talak semakin memudar, dan akhirnya lahirnya fatwa MUI tersebut di atas.

\section{Pembahasan}

\section{Konsep Perundang-undangan Perkakwinan Kontemporer}

Masalah taklik talak dan/atau perjanjian perkawinan dicantumkan dalam PerundangUndangan Perkawinan Indonesia dan sejumlah negara Muslim lain. Dalam Perundang-Undangan Indonesia dicantumkan dalam UU No. 1 tahun 1974 tentang Perkawinan dan Kompilasi Hukum Islam (KHI). Dalam UU NO. 1 Tahun 1974 dicantumkan pada Bab V, pasal 29, sementara dalam $\mathrm{KHI}$ dicantumkan pada Bab VII pasal 45 s/d 52. Isi selengkapnya dari Bab V, pasal 29 adalah sebagai berikut:

1) Pada waktu atau sebelum perkawinan dilangsungkan, kedua pihak atas persetujuan bersama dapat mengadakan perjanjian tertulis yang disahkan oleh Pegawai pencatat perkawinan, setelah mana isinya berlaku juga terhadap pihak ketiga sepanjang pihak ketiga tersangkut.

2) Perjanjian tersebut tidak dapat disahkan bilamana melanggar batasbatas hukum, agama dan kesusilaan.

3) Perjanjian tersebut mulai berlaku sejak perkawinan dilangsungkan.

4) Selama perkawinan berlangsung perjanjian tersebut tidak dapat dirubah, kecuali bila dari kedua belah pihak ada persetujuan untuk merubah dan perubahan tidak merugikan pihak ketiga.

Dalam Counter Legal Draft juga dicantumkan masalah perjanjian perkawinan, pada Bab V, pasal 21 dan 22. Selengkapnya isi pasal ini adalah berikut. Pasal 21, "sebelum perkawinan dilangsungkan, calon suami dan calon isteri dapat mengadakan perjanjian perkawinan tertulis yang disahkan oleh Pegawai Pencatat Perkawinan selama tidak bertentangan dengan undang-undang ini". Pasal 22, "Perjanjian Perkawinan dapat meliputi pembagian harta, perwalian anak, jangka masa perkawinan, dan perlindungan dari kekerasan".

Adapun konsep taklik talak dan perjanjian perkawinan dalam Perundangundangan Perkawinan negara-negara muslim, di luar Indonesia dapat digambarkan secara singkat sebagai berikut. Bahasan dimulai dari negara-negara Asia Tenggara dan hanya bahasan singkat.

Pertama dimulai dari PerundangUndangan Keluarga Muslim Malaysia, dimana disebutkan juga adanya kemungkinan membuat taklik talak dan perjanjian perkawinan. Kemungkinan ini disebutkan misalnya pada pasal 22 UndangUndang Selangor (Islamic Family Law of State of Selangor, Enactment 2003).

Adapun alasan yang dapat dimasukkan dalam taklik talak ada tiga. Pertama, suami meninggalkan isteri selama 4 bulan, disengaja atau tidak. Kedua, suami tidak memberikan nafkah sementara isteri patuh kepada suami. Ketiga, suami melakukan sesuatu yang membuat isteri cacat/sakit. Sekedar tambahan, hukum mengucapkan sighat taklik talak di Malaysia tidak wajib, namun tetap berlaku meskipun tidak diucapkan. 
UNISIA, Vol. XXXI No. 70 Desember 2008

Dalam Perundang-undangan Keluarga Singapore, kemungkinan taklik talak dicantumkan dalam Formulir (form) No. 4. Dalam form ini diberikan kemungkinan kepada isteri mengajukan perpisahan dengan empat alasan. Pertama, suami meninggalkan isteri selama 4 bulan, disengaja atau tidak. Kedua, suami tidak memberikan nafkah sementara isteri patuh kepada suami. Ketiga, suami melakukan sesuatu yang membuat isteri rusak/sakit badan dan hartanya, dan menyebabkan kehilangan kehormatan. Alasan ini berlaku dengan syarat isteri mengadukan ke pengadilan, ketika pengaduan terbukti, maka jatuh talak satu.

Sementara dalam perundang-undangan Perkawinan Maroko, masalah taklik talak dicantumkan pada pasal 31 the Code of Personal Status 1957-1958 (Qanûn alAkhwâl al-Syakhsîyah). Isi dari pasal ini bahwa isteri boleh menetapkan dalam akad nikah bahwa suaminya tidak akan poligami. Jika suaminya berpoligami, isteri berhak mengajukan perceraian. Isi dari pasal ini secara khusus hanya menyinggung poligami sebagai alasan kemungkinan terjadi perceraian, yang diajukan isteri karena keberatan.

Kedua, dalam Qanûn al-Akhwâl alSyaksîyah Syria no. 59 tahun 1953, masalah taklik talak dicantumkan dalam pasal 14. Pada ayat (i) disebutkan, manakala dalam satu akad nikah dibuat taklik talak yang bertentangan dengan syari'at, maka takliknya tidak sah, tetapi akad nikahnya sendiri tetap sah. Ayat (ii) dalam satu akad nikah yang menetapkan taklik talak untuk kepentingan isteri, maka ketetapan berlaku, dengan syarat tidak bertentangan dengan syari'at, tidak merugikan pihak ketiga, dan tidak menghilangkan hak suami. Ayat (iii) dimana isteri menetapkan taklik dalam akad nikah, yang menghilangkan hak pihak ketiga atau hak isteri, meskipun berlaku bagi suami, tetapi dapat menjadi dasar bagi isteri untuk minta cerai apabila dilanggar suami. Dalam pasal ini tidak disebutkan dan tidak dibatasi alasan yang boleh dicantumkan dalam taklik talak. Dengan aturan ini malah memungkinkan mencantumkan cakupan alasan yang lebih luas. Menurut beberapa penelitian, alasan yang paling umum dicantumkan dalam taklik talak Syria adalah suami tidak boleh pergi ke luar negeri mencari pekerjaan. Alasan ini didorong oleh kenyataan banyaknya kasus suami yang pergi mencari pekerjaan di luar negeri, namun kemudian tidak pulang lagi dan menikah lagi di negara tempat tinggalnya. Fenomena ini menjadi momok bagi wanita dan orang tua di Syria.

Ketiga, dalam Undang-Undang Yaman Utara tahun 1978 (Qanûn al-Usrah), masalah taklik talak dicantumkan dalam pasal 4 , bahwa satu perkawinan yang ada taklik (perjanjian perkawinan) yang sah dan berlaku bagi pihak-pihak, maka perkawinannya adalah sah dan perjanjian pun berlaku. Kemudian ditambahkan, perjanjian tidak boleh dirubah kecuali atas persetujuan bersama.

Keempat, Undang-Undang Lebanon Law on Family Rights 1917-1962, yang dicantumkan dalam pasal 38. Pasal ini berisi, ketika seorang wanita menetapkan dengan suaminya bahwa suami tidak poligami, maka tindakan poligami suami dapat menjadi alasan isteri untuk minta talak, baik isteri pertama maupun isteri kedua.

Kelima, kemungkinan taklik talak dalam Undang-Undang Perkawinan Somalia (Family Code of Somalia No. 23 Tahun 1975) dicantumkan dalam pasal 43. Pasal ini memuat sejumlah alasan yang memungkinan pasangan suami dan isteri untuk berpisah. Alasan-alasan dimaksud ada tujuh (7) yaitu: 
1. salah satu pasangan mengidap penyakit yang menghalangi mereka mengadakan hubungan seksual, dan penyakit dimaksud dibuktikan oleh hasil pemeriksaan (keterangan) dokter,

2. tidak diketahui keberadaanya selama empat tahun,

3. fakir miskin yang mengakibatkan suami tidak dapat mencukup nafkah keluarga,

4. kedua suami dan isteri miskin, dan mereka tidak dapat menyelesaikannya selama enam bulan,

5. terjadi perselisihan serius antara pasangan suami dan isteri, dan juru damai (arbitrador) tidak mampu mendamaikan,

6. salah satu pasangan tidak dapat melakukan hubungan seksual, dan

7. isteri berhak mintai cerai disebabkan suami poligami yang diijinkan oleh hakim, sesuai dengan pasal 13.

Isi pasal 13 Hukum Perkawinan Somalia adalah kemungkikan poligami bagi suami dan harus mendapatkan ijin dari pengadilan dengan sejumlah alasan. Alasan-alasan dimaksud adalah:

1. isteri mandul yang dibuktikan dengan surat keterangan dokter,

2. isteri mengidap penyakit berkepanjangan (tidak dapat disembuhkan) dan mengakibatkan tidak dapat melakukan hubungan seksual, yang dibuktikan oleh dokter,

3. isteri dipenjara lebih dari satu tahun,

4. isteri meninggalkan rumah tanpa alasan yang jelas, dan

5. karena ada kepentingan sosial, yang ijin untuk ini dikeluarkan oleh menteri kehakiman dan menteri agama.

Dengan demikian, dalam perundangundangan Somalia, meskipun ada kemungkinan poligami, dengan ijin dan dengan syarat-syarat tertentu, tetapi poligami suami ini dapat menjadi alasan isteri minta cerai.

\section{Taklik Talak dan Perjanjian Perkawinan Menjamin Perempuan}

Dalam menggunakan konsep taklik talak dan perjanjian perkawinan dalam menjamin hak-hak perempuan (isteri) dan melindungi mereka dari perlakuan diskriminatif suami masih minimal oleh masyarakat Indonesia. Bahkan taklik talak, lebih khusus lagi mengucapkan sighat taklik talak, hanya sekedar tradisi, belum disadari sebagai kesempatan untuk mendapat jaminan hak dan perlindungan. Karena itu, kesempatan yang diberikan undang-undang belum digunakan secara baik dan maksimal oleh masyarakat Indonesia. Konsep ini banyak digunakan kalangan artis Indonesia. Belum maksimalnya penggunaan konsep ini oleh masyarakat Indonesia menurut hemat penulis minimal karena dua alasan pokok. Pertama, kesadaran tentang pentingnya dan pengertian tentang tujuan konsep ini belum dipahami secara sempurna. Kedua, ada kekhawatiran bahwa dengan memasukkan taklik talak dan/atau perjanjian perkawian dalam akad perkawinan seolah perkawinan bukan untuk selama-lamanya. Sebab kalau di awal saja sudah ada taklik talak dan/atau perjanjian perkawinan seolah menjadi isyarat atau salah satu tanda perkawinan bukan untuk selamanya. Dengan demikian, memasukkan taklik talak dan atau perjanjian dalam akad perkawinan belum dipahami sebagai salah satu usaha preventif agar dapat terjamin hak dan terhindar dari kemungkinan perlakuan semena-mena suami.

Karenaitu dan sekaligus sebagai salah satu jalan keluar dari dua penyebab tersebut, penting dilakukan sosialisasi konsep ini kepada masyarakat secara baik dan maksimal. Dengan 
UNISIA, Vol. XXXI No. 70 Desember 2008

sosialisasi diharapkan muncul pemahaman yang benar dan lengkap tentang konsep taklik talak dan/atau perjanjian perkawinan. Dengan pemahaman yang benar dan lengkap ini pada gilirannya diharapkan dapat digunakan secara benar dan tepat pula. Sebab munculnya sejumlah kasus di sejumlah daerah boleh jadi disebabkan salah satunya oleh perasaan lakilaki (suami) yang merasa tidak salah melakukan tindakan sewenang-wenang. Dengan takliktalak dan/atau perjanjian perkawinan, diharapkan menjadi salah satu alat untuk melindungi perempuan dari tindakan-tindakan sewenangwenang tersebut.

\section{Penutup}

Ada tiga kesimpulan yang dapat dicatat dari bahasan tersebut di atas. Pertama, konsep taklik talak dan/atau perjanjian perkawinan telah lama dikenal di Indonesia, meskipun yang mengenal belum mayoritas, bahkan masih sangat terbatas di kalangan tertentu. Kedua, ketersediaan aturan taklik talak dan/atau perjanjian perkawinan sejak awal sampai muncul dalam PerundangUndangan Perkawinan Indonesia, bertujuan untuk menjamin hak-hak isteri dan melindungi mereka dari tindakan diskriminatif dan sewenang-wenang laki-laki (suami). Ketiga, meskipun konsep ini sudah lama eksis, tetapi belum dipahami secara lengkap oleh masyarakat pada umumnya. Kurang pemahaman terhadap konsep ini disebabkan salah satu oleh kurangnya sosialisasi. Karena itu upaya sosialisasi perlu dilakukan secara terus menerus dan substansial.

\section{Daftar Pustaka}

Kamus Arab-Indonesia,t.t.Yunus, M. Mahmud. Jakarta: Yayasan Penyelenggaraan Penterjemahan/Pentafsiran al-Qur'an.
Manan,Abdul,2000. Penerapan Hukum Acara Perdata di Lingkungan Peradilan Agama. Jakarta: Yayasan Al-Hikmah.

Abdurrahman,1992. Kompilasi Hukum Islam di Indonesia. Jakarta: Akademika Pressindo.

Gunaryo,Ahmad t.t.Pergumulan Politik Hukum Islam di Indonesia. Jakarta: tanpa.

Ahmad,Amrullah dkk. (Ed),1994. Prospek Hukum Islam dalam Kerangka Pemba-ngunan Hukum Nasional di Indonesia Sebuah Kenangan 65 Tahun Prof.Dr.H.Busthanul Arifin, $S H$,. Jakarta: PP-IKAHA.

Bakry,Hasbullah,1978. Kumpulan Lengkap Undang-Undang dan Peraturan Perkawinan di Indonesia. Jakarta: Penerbit Djembatan.

Mahmood,Tahir .1978. Personal Law in Islamic Countries. New Delhi, Times Press.

Tim Pengarusutamaan Gender Depag. R.I.2004., Pembaruan Hukum Islam: Counter Legal Draft Kompilasi Hukum Islam. Jakarta: Pengarusutamaan Gender Depag. R.I.

Tim Penyunting MUI, 1997. Himpunan Fatwa Mejelis Ulama Indonesia. Jakarta: MUI.

Noeh,Zaini Ahmad,1997. "Pembacaan Sighat Taklik Talak Sesudah Akad Nikah", Jurnal Mimbar Hukum. No. 30 , th. VIII. 